\title{
EXHALED AIR ANALYSIS IN PATIENTS WITH DIFFERENT LUNG DISEASES USING ARTIFICIAL ODOUR SENSORS
}

\author{
Immanuels Taivans*, Normunds Jurka*, Līga Balode*, Māris Bukovskis**, \\ Uldis Kopeika**, Vadims Ogorodniks***, Jānis Kleperis**, Gunta Strazda*, \\ Viesturs Šilinšs**, and Agris Martinsons** \\ * Faculty of Medicine, University of Latvia, Šarlotes iela 1a, Rīga, LV-1001, LATVIA \\ ** Pauls Stradiṇš Clinical University Hospital, Pilsoṇu iela 13, Rīga, LV-1002, LATVIA \\ *** Institute of Solid State Physics, University of Latvia, K̦engaraga iela 8, Rīga, LV-1021, LATVIA
}

Communicated by Andrejs Ërglis

\begin{abstract}
Sniffing breath to diagnose a disease has been practiced by doctors since ancient times. Nowadays, electronic noses are successfully used in the food, textile and perfume industry as well as for air pollution control. The aim of this study was to test whether exhaled breath analysed by an artificial nose could identify and discriminate between different lung diseases. A total of 76 individuals were tested: 25 bronchial asthma, 19 lung cancer, 10 pneumonia, 6 chronic obstructive pulmonary disease (COPD) patients and 16 healthy volunteers. Exhaled air was collected in plastic bags and immediately analysed using an electronic nose instrument (9185, Nordic Sensors $A B)$ containing 14 different odour sensors. Multifactor logistic regression analysis was used to determine correlation between the amplitudes of sensor responses and the clinical diagnoses of patients and to calculate sensitivity and specificity of the method for each diagnosis. For diagnostics of asthma the sensitivity was found to be $84 \%$ and specificity - $86 \%$. For lung cancer, the sensitivity was $74 \%$ and specificity, 95\%; for pneumonia $90 \%$ and $98 \%$, but for COPD, 33\% and $97 \%$, respectively. We conclude that an artificial nose is able to discriminate among different lung diseases with sufficiently good accuracy. This method may be further developed to implement it in clinical medicine for express diagnostics of acute and chronic lung diseases.
\end{abstract}

Key words: exhaled air analysis, electronic nose, lung diseases.

\section{INTRODUCTION}

Doctors have been sniffing breath for indications of disease since the days of Hippocrates. The sweet smell of acetone is a flag for diabetes, and advanced liver disease is said to make the breath reek of fish. At present, approximately 200 different volatile organic compounds have been detected in exhaled human air. The most abundant volatile metabolites of exhaled breath in healthy humans are ammonia, acetone, methanol, ethanol and isoprene that are present at concentrations of several hundred parts per billion ( $\mathrm{ppb}$ ) (Smith et al., 2007). Volatile compounds are transferred to exhaled air from blood and they represent the metabolic processes in human body.

However, breath odour is significantly affected by evaporations from the surfaces of mouth, pharynx and respiratory tract. For instance, people having bad breath due to oral conditions exhale high concentrations of hydrogen sulphide and methyl mercaptane (Kurata et al., 2008). These products are produced by bacteria invading the mucosa and products arising from inflamed tissue (Harszthy et al., 2008; Saad and Greenman, 2008).
Recently it was found that lung cancer patients exhale higher amounts of alkanes and methylated alkanes than healthy persons (Phillips et al., 2003).

A classical method for detection of volatile organic compounds (VOCs) in breath is gas chromatography and mass spectrometry. However, this method is time consuming, expensive and requires experienced personnel. Therefore, several new approaches are being implemented for detection of VOCs in exhaled air applicable for express diagnostics by the bedside bench.

Frishman et al. (2001) developed a small, fast acting chromatograph with a flame ionisation detector producing its own hydrogen and oxygen as carrier gases by water electrolysis. The device allowed to analyse exhaled breath within one minute with the detection limit sub $1 \mathrm{ppb}$ (Frishman et al., 2001).

Another approach is to use the so-called electronic nose. It consists of a set of sensors specifically reacting to particular chemical compounds in low concentrations. Such devices are used in some industrial fields - perfume, textile manu- 
facturing, air pollution monitoring, etc. Electronic nose instrument compared to gas chromatograph is cheap, handy, and the measurement time is short — only several minutes compared to classical gas chromatography that takes more than an hour. Several investigators tested the electronic nose for measurement of VOC's in exhaled air. Machado et al. (2005) checked exhaled air of lung cancer patients and compared it with healthy controls. They found $71 \%$ sensitivity and $91 \%$ specificity for detecting cancer by this method (Machado et al., 2005).

We hypothesised that besides lung cancer, other chronic and acute lung diseases could be diagnosed by exhaled breath analysis. Therefore, in this study we analysed exhaled air of patients with bronchial asthma, chronic obstructive lung disease, pneumonia, and lung cancer using electronic nose device and compared the data with healthy volunteers.

\section{MATERIALS AND METHODS}

In total, 76 individuals were included in this study. 25 patients had asthma, 19 - lung cancer, 10 - pneumonia, and 16 were healthy volunteers. Before the gas sample collection, to minimise the influence of oral odour, patients were asked to rinse their mouth and throat with pure water. Then they performed full inspiration from ambient air, held their breath for two seconds and then exhaled deeply into a plastic bag (1.5 1 disposable lavsan baking bag, connected to silicone mouthpiece). Gas samples were analysed within two minutes by an electronic nose instrument (Nordic Sensors AB, Linköping, Sweden). After each analysis the instrument was purged two times by ambient air. The electronic nose contained 14 different odor sensors. Ten were MOFSET sensors with different gas sensing electrodes $(\mathrm{Pt}$, $\mathrm{Pd}$, Ir and their alloys, with working temperatures $115^{\circ} \mathrm{C}$ and $\left.150{ }^{\circ} \mathrm{C}\right)$ and four were resistive high-temperature $(\approx 350$ $\left.{ }^{\circ} \mathrm{C}\right) \mathrm{SnO}_{2}$ Taguchi gas sensors — TGS-813;800; 881; and 825. Sample gas was pumped into the device at a speed of $8 \mathrm{ml} / \mathrm{min}$.

Data were analysed by software programme Statistica 7 generalised linear/nonlinear models (GLZ) multiple logistic regression (logit line function) with multinomial distribution. To elaborate equations for calculation of prognostic levels of a particular diagnosis based on sensor data, as the depending factor we chose diagnosis, but as continuator predictor - the outputs of 14 sensors.

The general formula for probability calculations of asthma diagnosis was the following:

$$
\begin{aligned}
& y_{\text {Asth }}=\frac{\exp \left(b_{0 \text { Asth }}+b_{1 \text { Asth }} \cdot x_{1}+\ldots+b_{13 \text { Asth }} \cdot x_{13}\right)}{1+\exp \left(b_{0 \text { Asth }}+b_{1 \text { Asth }} \cdot x_{1}+\ldots+b_{13 \text { Asth }} \cdot x_{13}\right)+} \\
& \exp \left(b_{0 \text { COPD }}+b_{1 \text { COPD }} \cdot x_{1}+\ldots+b_{13 \text { COPD }} \cdot x_{13}\right)+ \\
& \exp \left(b_{0 \text { Canc }}+b_{1 \text { Canc }} \cdot x_{1}+\ldots+b_{13 \text { Canc }} \cdot x_{13}\right)+ \\
& \exp \left(b_{0 \text { Р пеи }}+b_{1 \text { Pпеи }} \cdot x_{1}+\ldots+b_{13 \text { Рпеи }} \cdot x_{13}\right),
\end{aligned}
$$

were y was probability level of diagnosis for particular patient, $\mathrm{b}$ - estimates for particular diagnosis, $\mathrm{x}$ - sensor output. Similar formulas were used for probability calculations of other diagnoses. The study was blinded for investigators.

We tested the following sensor output characteristics: maximal amplitude, slope of ascending limb and the area under the curve. Preliminary regression analysis showed the closest correlation between the amplitudes of sensor responses and particular diagnosis (asthma, COPD, pneumonia, or lung cancer), the slope of ascending limb and area under the curve being less close predictors. The regression model was optimised by stepwise exclusion of least informative sensors that did not influence significantly the sensitivity and specificity of the result. Finally, after exclusion of data given by sensor MOSFET10 we obtained a multiple logistic regression model consisting of four equations, each for particular diagnosis that was used for a further data analysis.

\section{RESULTS}

The exhaled air of patients with particular disease activated some specific set of sensors. Figure 1 represents the probability of the response of particular sensors in the cases of particular diseases. The probability here is represented as a $P$ value. No sensor was specific for a particular disease. For instance, in the case of lung cancer, with highest probability response was associated with MOSFET2 sensor. However, this sensor responds with high probability also in the cases of asthma. The MOSFET6 sensor responds with high probability to the air of cancer, asthma and COPD patients. Precise values of each sensor response probability in particular disease cases, together with estimate values and their confidence limits, are given in the Table 1. Estimate values were used further in regression equations.

Not regarding the lack of a specific sensor for a particular disease, the set of responding sensors differed for each disease. This is evident from the results of the multiple logistic regression analysis within investigated disease groups (Table 2).

From 25 patients with clinically approved diagnosis of asthma, the regression model on the basis of sensor signal analysis predicted the same diagnosis in 21 cases. In one case it erroneously predicted lung cancer, but in three cases considered the patient healthy. This means that the sensitivity of the method for diagnostics of asthma is $84 \%$ (correct diagnosis versus all asthma patients). However, the time regression model predicted asthma in seven patients that did not have this diagnosis. Three of them were healthy, two had lung cancer and one had COPD. This means that the specificity of the method for diagnostics of asthma is $86 \%$ (correctly diagnosed as no asthma versus group of no asthma patients).

The highest sensitivity and specificity of the method was found for pneumonia - $90 \%$ and $98 \%$ but for lung cancer $-74 \%$ and $95 \%$, respectively. 

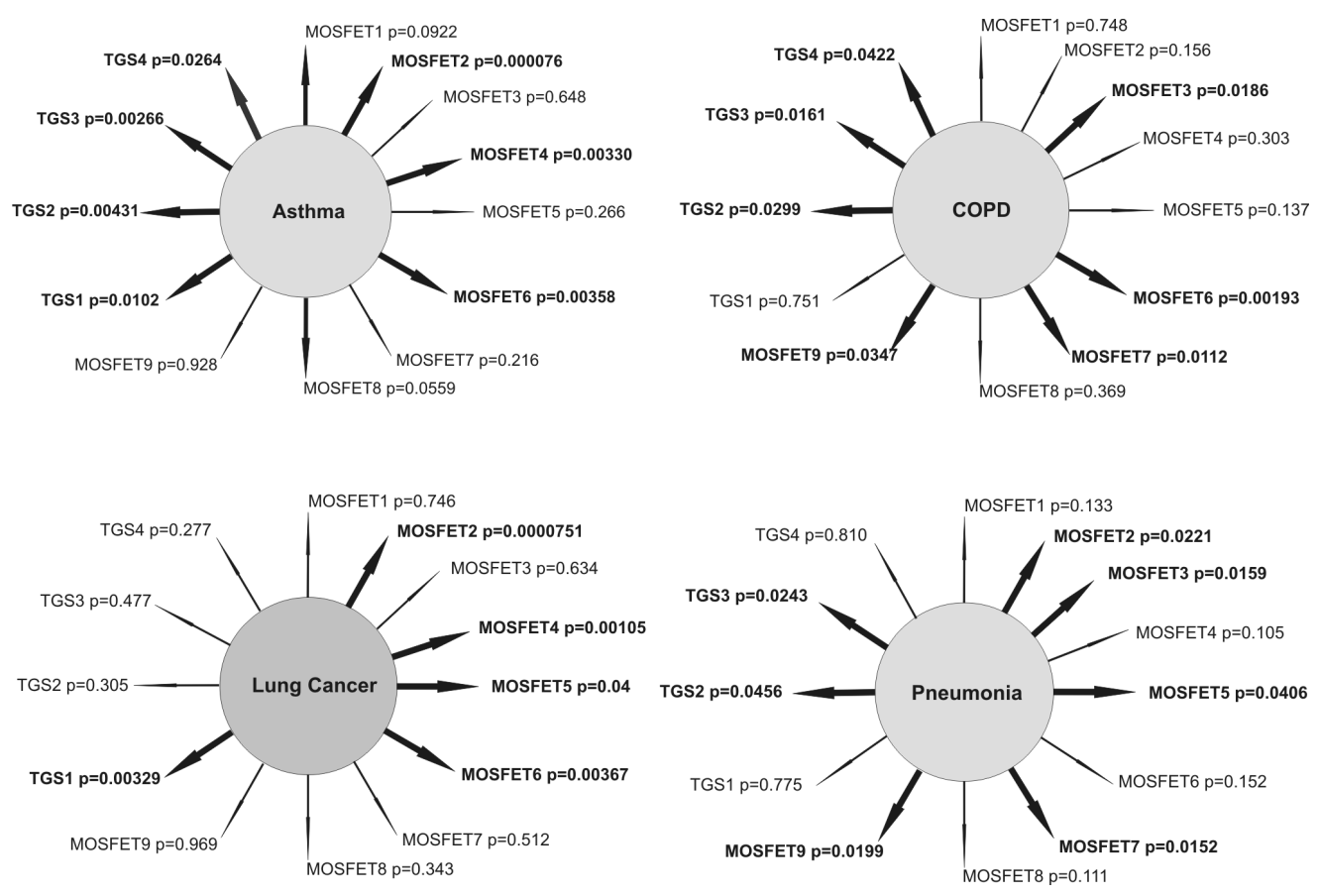

Fig. 1. $P$ values of individual sensor response amplitudes to exhaled air within examined disease groups.

Table 1

Table 2

ESTIMATES, CONFIDENCE LIMITS AND $P$ VALUES OF INDIVIDUAL SENSOR RESPONSE AMPLITUDES TO EXHALED AIR WITHIN EXAMINED DISEASE GROUPS

\begin{tabular}{|c|c|c|c|c|c|}
\hline \multirow[b]{2}{*}{ Effect } & \multicolumn{5}{|c|}{$\begin{array}{l}\text { Distribution : MULTINOMIAL } \\
\text { Link function: LOGIT }\end{array}$} \\
\hline & \begin{tabular}{|l|} 
Level of \\
Response
\end{tabular} & Estimate & $\begin{array}{l}\text { Lower } \\
\mathrm{CL} \\
95 \%\end{array}$ & $\begin{array}{l}\text { Upper } \\
C L \\
95, \%\end{array}$ & $p$ \\
\hline Intercept 1 & Asthma & 2,925777 & $-4,44254$ & 10,29409 & 0,436420 \\
\hline MOSFET 1 & Asthma & $-1,491260$ & $-3,22695$ & 0,24443 & 0,092191 \\
\hline MOSFET 2 & Asthma & $-7,079773$ & $-10,58750$ & $-3,57205$ & 0,000076 \\
\hline MOSFET 3 & Asthma & 3,390513 & $-11,17973$ & 17,96075 & 0,648328 \\
\hline MOSFET 4 & Asthma & 8,557321 & 2,84863 & 14,26601 & 0,003304 \\
\hline MOSFET 5 & Asthma & $-2,566101$ & $-7,08426$ & 1,95206 & 0,265636 \\
\hline MOSFET 6 & Asthma & 5,973462 & 1,95475 & 9,99217 & 0,003576 \\
\hline MOSFET 7 & Asthma & 0,944935 & $-0,55306$ & 2,44293 & 0,216330 \\
\hline MOSFET 8 & Asthn & 13,200883 & $-0,33336$ & 26,73513 & 0,055916 \\
\hline MOSFET 9 & Asthm & $-0,074814$ & $-1,70469$ & 1,55507 & 0,928315 \\
\hline TGS 1 & Asthma & 7,214028 & 1,71384 & 12,71422 & 0,010150 \\
\hline TGS & Asth! & 1,640820 & 0,51 & 2,76727 & 0,004305 \\
\hline & Asthi & $-2,4488$ & $-4,04$ & $\begin{array}{r}-0,85158 \\
\end{array}$ & 0,002657 \\
\hline TGS & Asthma & 1,063704 & 0,12501 & 2,00240 & 0,026352 \\
\hline ept 2 & COPD & $-9,256544$ & $-21,73992$ & 3,22683 & 0,146132 \\
\hline FET 1 & COPD & 0,428177 & $-2,18723$ & 3,04358 & 0,748307 \\
\hline DSFET 2 & COPD & $-4,242532$ & $-10,10941$ & 1,62435 & 0,156391 \\
\hline & COPD & $-49,548977$ & $-90,80189$ & $\begin{array}{r}-8,29606 \\
\end{array}$ & \\
\hline FET 4 & COPD & 5,508125 & $-4,97832$ & 15,99457 & 0,303248 \\
\hline MOSFET 5 & COPD & 6,562046 & $-2,07915$ & 15,20324 & 0,136651 \\
\hline & COPD & 10,2518 & & 16,7 & \\
\hline & COPD & 5,174 & 1,17691 & 9,17182 & 0,011180 \\
\hline SFET 8 & COPD & $-12,073213$ & $-38,42879$ & 14,28237 & 0,369272 \\
\hline SFET 9 & COPD & & & & \\
\hline & & & $-10,84$ & & 0,751302 \\
\hline & COPD & 2,290971 & 0,22269 & 4,35925 & 0,029932 \\
\hline & COPD & & & & \\
\hline & COPD & & & & \\
\hline ept 3 & Lung Cancer & 181 & $-6,65478$ & 94 & 0,850682 \\
\hline & g Cancer & & & & 0,746 \\
\hline & I Cane & $-5,847812$ & $-9,24868$ & $-2,44694$ & 0,000751 \\
\hline FET 3 & Canc & $-3,386339$ & $-17,31884$ & 10,54617 & 0,633807 \\
\hline ET 4 & Canc & & & 15,34 & 0,001 \\
\hline ET 5 & Can & & $-8,74$ & & \\
\hline MOSFET 6 & g Canc & & 2,14 & 11,02238 & \\
\hline ET 7 & Car & & $-0,8$ & & 0,512 \\
\hline & g Can & & $\begin{array}{l}-0,0747 \\
-5,77\end{array}$ & 16,60 & \\
\hline FET 9 & g Can & & $-1,30608$ & 1,25460 & 0,968 \\
\hline & g Can & & & & \\
\hline & Lung Cancer & & $\begin{array}{r}-0,27 \\
-0,0\end{array}$ & & \\
\hline & Cancer & & $-1,16854$ & 06 & 0,476 \\
\hline TGS & Can & & & & \\
\hline & eumon & $-23,99$ & $-47,22357$ & $\begin{array}{r}-0,77495 \\
-0,74\end{array}$ & \\
\hline & eumon & & $-0,87299$ & 6,59563 & 0,13 \\
\hline ET 2 & & & $\begin{array}{r}-11,6 \\
-11,6\end{array}$ & & \\
\hline & eumor & $-75,7$ & 137,35667 & $-14,19357$ & 0,015878 \\
\hline & & & & & \\
\hline FET 5 & & & & 41,012 & \\
\hline SFET 6 & Pneumon & & $-1,34147$ & 8,59599 & \\
\hline & & & & 14,99 & \\
\hline DSFET 8 & Pneumonia & $-37,1$ & $-82,86$ & 8,57586 & 0,1113 \\
\hline MOSFET 9 & Pneumonia & $-6,757004$ & $-12,44656$ & $-1,06745$ & 0,019929 \\
\hline & & $-1,580311$ & & & 0,774983 \\
\hline & Pneumol & & & 5,97888 & 0,045572 \\
\hline TGS & Pneumonia & $-4,832815$ & $-9,03924$ & $-0,62639$ & 0,024333 \\
\hline TGS 4 & Pneumonia & 0.251843 & $-1,79698$ & 2,30067 & 0,809617 \\
\hline
\end{tabular}

CLINICALLY STATED DIAGNOSES VERSUS TRUE AND FALSE PREDICTED DIAGNOSES BY MULTIPLE LOGISTIC REGRESSION MODEL

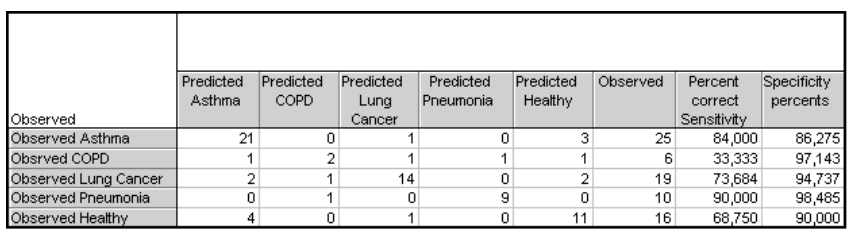

\section{DISCUSSION}

The obtained results suggest that mathematical analysis of the impact of each of 13 odour sensors of electronic nose allows to predict different lung diseases with reasonable accuracy. Specificity and sensitivity of our method is close to values reported by Mascado et al. (2005). Their model for lung cancer prediction had $71.4 \%$ sensitivity and $91.9 \%$ specificity. We showed that other lung diseases like bronchial asthma, pneumonia and COPD have specific patterns of exhaled air that may be detected by electronic nose.

Exhaled air analysis for diagnostic purposes differs from conventional diagnostic approaches that are based on the measurement of blood or other body fluids level of particular substances reflecting body metabolism. There is no particular substance characteristic for lung cancer or other lung disease. A specific smell that is recognised by trained dogs or an electronic nose is made up of a mixture of different substances in different concentrations. The total amount of these substances may reach a hundred and even more. Therefore, it is not surprising that we cannot find a sensor that specifically responds to a particular disease.

At the same time, multiple analysis of responses from a set of different sensors required sophisticated mathematical 
methods. During the last decades, such methods have been developed and it opened the door for the progress in electronic nose measurements (Wold et al., 1987; Kermany et al., 1999; Furey et al., 2000).

Similarities in sensor responses in the cases of different diseases have also another explanation. All of the examined diseases in our study were inflammatory in nature. Even in healthy lungs the inflammatory process is constantly active, as both macrophages and neutrophilic leukocytes permanently destroy microorganisms that enter the lungs with inhaled air. The difference is more quantitative than qualitative. Perifocal inflammation occurs around the tumour; asthma is recognised as an aninflammatory disease with predominant eosinophil involvement; COPD is a chronic inflammatory disease of small airways and lung parenchyma; and pneumonia is an inflammatory disease with massive neutrophils involvement. During the inflammatory process, oxidative burst occurs in leukocytes resulting in peroxidation of membrane phospholipids and production of alkanes such as ethane and pentane and methylated alkanes (Risby et al., 1999; Skeldon et al., 2006). In cancer cells, due to activation of cytochrome P450 (CYP)-mixed oxydase enzymes the degradation of volatile alkanes and methylated alkanes is enhanced, which is reflected in a somewhat different spectrum of odour sensor response (Watanabe, 1998).

We conclude that an artificial nose is able to discriminate among different lung diseases with sufficiently good accuracy. This method may be further developed to implement it in clinical medicine for express diagnostics of acute and chronic lung diseases.

\section{ACKNOWLEDGEMENT}

The work was supported by the National Research Programme in Medicine 2006-2009, project No. 13, ,Chronic respiratory diseases: timely and effective diagnostics, implementation of new treatment methods".

\section{REFERENCES}

Frishman, G., Tzanani, N., Amirav A. (2001). Electrolyzer operated gas cylinder free GC-FID. Field Anal. Chem. Technol., 5, 107-115.

Furey, T.S., Cristianini, N., Bednarski, D.W., Schummer, M., Haussler, D. (2000). Support vector machine classification and validation of cancer tissue samples using microarray expression data. Bioinformation, 16, 906-914.

Haraszthy, V.I., Gerber, D., Clark, B., Moses, P., Parker, C., Sreenivasan, P.K., Zambon, J.J. (2008). Characterization and prevalence of Solobacterium moorei associated with oral halitosis. J. Breath Res., 2, DOI: 10.1088/1752-7155/2/1/017002.

Kermany, B.G., Schiffman, S.S., Nagle, H.T. (1999). Using neural networks and genetic algorithms to enhance performance in an electronic nose. IEEE Trans. Biomed. Eng., 46, 429-439.

Kurata, H., Awano, S., Yoshida, A., Ansai, T., Takehara, T. (2008). Volatile sulphide compound levels in mouth air with plaque-related periodontal disease are associated with a change in the proportion of periodontopathic bacteria in saliva. J. Breath Res., 2, DOI: 10.1088/1752-7155/2/1/017006.

Machado, R., Laskowski, D., Deffenderfer, O., Burch, T., Zheng, S., Mazzone, P.J., Mekhail, T., Jennings, C., Stoller, J.K., Pyle, J., Duncan, J., Dwelk, R.A. (2005). Detection of lung cancer by sensor array analyses of exhaled breath. Amer. J. Respir. Crit. Care Med., 171, 1286-1291.

Phillips, M., Cataneo, R.N., Cummin, A.R., Gagliardi, A.J., Gleeson, K., Greenberg, J., Maxfield, R.A., Rom, W.N. (2003). Detection of lung cancer with volatile markers in the breath. Chest, 123, 2115-2123.

Risby, T.H., Sehnert, S.S., (1999). Clinical application of breath biomarkers of oxidative stress status. Free Radic. Biol. Med., 27, 1182-1192.

Saad, S., Greenman, J. (2008). Tongue biofilm areal density and tongue coating index J. Breath Res., 2, DOI: 10.1088/1752-7155/2/1/017008.

Skeldon, K.D., McMillan, L.C., Wyse, C.A., Monk, S.D. (2006). Application of laser spectroscopy for measurement of ethane in patients with lung cancer. Respir. Med., 100, 2, 300-306.

Smith, D., Turner, C., Španel, P. (2007). Volatile metabolites in the exhaled breath of healthy volunteers: Their levels and distributions. J. Breath Res., 1, DOI: 10.1088/1752-7155/1/1/014004.

Watanabe, N. (1998). Polymorphic CYP genes and disease predisposition-what have the studies shown so far? Toxicol. Lett., 102-103, 167-171.

Wold, S., Ebensen, K., Geladi, P. (1987). Principal component analysis. Chemom. Intell. Lab. Syst., 2, 37-52.

Received 11 July 2009

\section{IZELPAS GAISA ANALĪZE PACIENTIEM AR DAŽĀDĀM PLAUŠU SLIMĪBĀM, IZMANTOJOT MĀKSLĪGOS OŽAS SENSORUS}

Jau kopš seniem laikiem ārsti ostījuši pacienta elpu, lai uzstādītu slimības diagnozi. Mūsdienās ir radīts elektroniskais deguns, un to izmanto gan smaržu, gan tekstilrūpniecībā, gan lai novērtētu vides piesārṇotību. Mūsu pētījuma mērķis bija noskaidrot, vai mākslīgo degunu var izmantot plaušu slimību diferenciāldiagnostikai. Pētījumā piedalījās 76 personas: 25 bronhiālās astmas slimnieki, 19 bija plaušu vēzis, 10 pneimonija, 6 - hroniska obstruktīva plaušu slimība (HOPS), bet 16 bija veseli brīvprātīgie. Izelpas gaisu savāca plastikāta maisos un to tūlīt analizēja ar elektroniskā deguna aparātu (Nordic Sensors AB, 9185), kura sastāvā bija 14 smaržu sensori. Lai konstatētu korelāciju starp smaržas sensoru rādījumiem un konkrētām pacientu diagnozēm, kā arī lai noteiktu metodes specifiskumu un jutību, tika lietota multifaktoru loǵistiskās regresijas analīze. Jutība, paredzot astmas diagnozi, bija 84\%, bet specifiskums - 86\%. Jutība, nosakot plaušu vēzi, bija $74 \%$, specifiskums - 95\%; pneimonijai $90 \%$ un 98\%, bet HOPS - attiecīgi 33\% un 97\%. Secinājām, ka elektroniskais deguns spēj atšķirt dažādas plaušu slimības ar pietiekamu precizitāti. Metodi varētu turpmāk attīstìt un lietot klīniskajā praksē akūtu un hronisku plaušu slimību ekspresdiagnostikai. 